\title{
ОЦІНКА РІВНЯ ХІРУРГІЧНОГО СТРЕСУ В ПЕРЕДОПЕРАЦІЙНИЙ ПЕРІОД ЗА МЕТОДИКОЮ LAZARUS
}

\author{
Н. В. Петренко, М. В. Хлівна \\ Тернопільський національний медичний університет \\ імені І. Я. Горбачевського МОЗ Украӥни
}

У статті проаналізовано ефективність використання методики Lazarus для визначення рівня хірургічного стресу в пацієнтів, яких готують до операційного лікування.

\section{EVALUATION OF SURGICAL STRESS IN THE PRE-OPERATIVE PERIOD BY LAZARUS METHOD}

\author{
N. V. Petrenko, M. V. Khlivna \\ I. Horbachevsky Ternopil National Medical University
}

The effectiveness of using the Lazarus technique to determine the level of surgical stress in patients preparing for surgery was analyzed in the article.

Вступ. Незважаючи на розвиток науки й техніки, залишається чимало захворювань, які потребують хірургічного лікування. Оскільки за сучасних умов традиційні методики проведення операційних втручань відійшли на другий план, поступившись місцем малоінвазивним технологіям [1], для кожної людини інвазія в її тіло, незважаючи на ії розміри, є втручанням у приватну сферу та стресогенним чинником, який може стати причиною відмови від операційного лікування. Високий рівень стресу утруднює проведення анестезії та сповільнює відновлення в післяопераційний період [2]. Тому визначення рівня хірургічного стресу в передопераційний період та запровадження відповідного менеджменту може значно покращити стан пацієнта та мінімізувати ускладнення в післяопераційний період.

Саме тому метою дослідження було визначення можливості використання копінг-стратегій як здатності до подолання періопераційного стресу за методикою Lazarus [3, 4].

Основна частина. Обстежено 68 пацієнтів, яких готували до хірургічного лікування в клініці «ГармоніяКР» м. Кривий Ріг. Серед них було 39 (57 \%) жінок та 29 (43\%) чоловіків.

(c) Н. В. Петренко, М. В. Хлівна, 2020
Середній вік обстежених пацієнтів становив $(45,0 \pm 12,5)$ року, серед яких було 14 (20\%) пацієнтів віком 21-35 років, 42 (62 \%) - віком 35-55 років та 12 (18\%) - віком 55-76 років.

Залежно від профілю операційного втручання, 37 (54 \%) пацієнтів готували до операції з приводу хірургічної патології, 19 (28\%) - гінекологічного захворювання та 12 (18\%) - травматологічного профілю.

Для визначення рівня напруження пацієнтів використано методику Lazarus. Ця методика дозволяє визначити копінг-механізми та способи подолання труднощів у різних сферах діяльності залежно від рівня напруження за кожною шкалою. Це обстеження передбачає визначення рівня напруження на основі 8 шкал.

У передопераційний період за шкалою «Конфронтаційний копінг» високий рівень напруження виявлено в 17 (25\%) пацієнтів, середній рівень - у 48 (71\%), а низький рівень - в 3 (4 \%).

Проведене нами дослідження показало, що особи жіночої статі мали вищий рівень напруження порівняно з чоловіками. Так високий рівень напруження було виявлено у 10 (26 \%) жінок та в 7 (24\%) чоловіків, середній рівень - у 29 (74 \%) жінок та в 19 (65 \%) чоловіків, а низький - у 3 (10\%) чоловіків. 
Неоднозначно на очікування операційного втручання реагували пацієнти залежно від віку. Так у віковій категорії 21-35 років високий рівень напруження виявлено в 11 (79 \%) пацієнтів, середній - у 3 (21\%). У віковій групі 35-55 років 6 (14\%) пацієнтів мали високий рівень напруження, 33 (79\%) - середній, а 3 (7 \%) - низький. У найстаршій віковій групі 55-76 років усі 12 (100\%) пацієнтів мали середній рівень напруження.

Рівень напруження відрізнявся залежно від профілю втручання. Нами встановлено, що високий рівень напруження був 5 (42 \%) пацієнтів травматологічного профілю, у 8 (22 \%) - хірургічного та в 4 (21\%) - гінекологічного. Середній рівень напруження мали 15 (79\%) пацієнтів із гінекологічною патологією, 26 (70 \%) - 3 хірургічною та 7 (58 \%) - з травматологічною. Легкий рівень напруження був наявний у 3 (8\%) пацієнтів хірургічного профілю.

Вивчення копінг-механізмів за шкалою «Дистанціювання» показало, що високий рівень напруження мали 16 (24 \%) пацієнтів, середній рівень - 51 (75\%) пацієнт, а легкий рівень - 1 (1\%) пацієнт.

Особи жіночої статі мали вищий рівень напруження порівняно з пацієнтами чоловічої статі. Так високий рівень напруження був виявлений у 14 (36 \%) жінок та 2 (7 \%) чоловіків, а середній рівень - у 26 (90\%) чоловіків та 25 (64 \%) жінок. Низький рівень виявлено у 1 (3\%) чоловіка.

Також була різна реакція на підготовку до операційного втручання залежно від віку, у пацієнтів вікової групи 21-35 років високий рівень напруження був у 8 (57\%) пацієнтів, а середній - в 6 (43\%). У віковій групі 35-55 років виявлено 6 (14,5 \%) пацієнтів із високим рівнем напруження, 35 (83,5 \%) - з середнім та 1 (2 \%) - з низьким рівнем. Високий рівень напруження мали 2 (17\%) пацієнти, 10 (83\%) - середній у віковій групі 55-76 років.

По-різному пацієнти реагували в передопераційний період залежно від профілю операційного втручання. Нами встановлено, що високий рівень напруження мав місце у 4 (33 \%) пацієнтів травматологічного профілю, в 6 (32 \%) - гінекологічного, а серед пацієнтів із хірургічними захворюваннями їх було 6 (16 \%). Середній рівень виявлено в 30 (81\%) пацієнтів хірургічного профілю, 13 (68 \%) - гінекологічного, 8 (67 \%) - травматологічного. Також у 1 (3 \%) пацієнта з хірургічною патологією виявлено легкий рівень.

У передопераційний період за шкалою «Самоконтроль» високий рівень напруження виявлено у
32 (47 \%) пацієнтів, з яких було 14 (48 \%) чоловічої статі та 18 (46 \%) - жіночої, середній рівень був у 33 (49 \%) пацієнтів, серед яких було 15 (52 \%) чоловіків та 18 (46 \%) жінок; легкий рівень напруження мали 3 (4 \%) жінок.

Високий рівень напруження частіше був виявлений у пацієнтів хірургічного профілю (22 (59 \%)), порівняно з пацієнтами, які мали травматологічну (4 (33 \%)) та гінекологічну патологію (6 (32 \%)). Необхідно зазначити, що у той самий час середній рівень мали 8 (67 \%) пацієнтів травматологічного профілю, 10 (53 \%) - гінекологічного та 15 (41 \%) - хірургічного. Низький рівень напруження мали тільки 3 (4 \%) пацієнти гінекологічного профілю.

Рівень напруження відрізнявся залежно від вікової групи пацієнтів, так всі 12 (100\%) пацієнтів найстаршої вікової групи (55-76 років) мали високий рівень напруження, тоді як у середній групі (35-55 років) таких пацієнтів виявлено 18 (43\%), а у віковій категорії 21-35 років - 2 (14\%). Середній рівень виявлено в 9 (64 \%) пацієнтів молодої вікової групи та у 24 (57 \%) середньої. Крім того, 3 (4 \%) пацієнтів наймолодшої вікової категорії мали легкий ступінь напруження.

Оцінки психологічного стану за шкалою «Пошук соціальної підтримки» серед пацієнтів, яких готували до операційного втручання, показали високий рівень напруження у 37 (54 \%) осіб, а середній - в 31 (46 \%) пацієнта.

За результатами дослідження, нами встановлено, що високий рівень напруження мали 27 (69\%) жінок та 10 (34 \%) чоловіків, а середній рівень - 19 (66 \%) пацієнтів чоловічої статі та 12 (31\%) - жіночої.

Різна реакція була в пацієнтів залежно від профілю захворювання, так високий рівень напруження мав місце у 9 (75 \%) пацієнтів із травматологічними захворюваннями, у 12 (63 \%) - з гінекологічними та у 16 (43 \%) - з хірургічними. Середній рівень напруження мали 21 (57 \%) пацієнт хірургічного профілю, 7 (37 \%) - гінекологічного та 3 (25 \%) - травматологічного.

Проведене дослідження показало, що всі 14 (100\%) пацієнтів вікової групи 21-35 років мали лише високий рівень напруження. У віковій групі 35-55 років 25 (60 \%) пацієнтів мали середній рівень, а 17 (40 \%) високий. У найстаршій віковій групі (55-76 років) високий та середній рівень напруження мали по 6 (50\%) пацієнтів.

У дослідженої групи пацієнтів за шкалою «Прийняття відповідальності» в передопераційний період 
виявлено середній рівень напруження в 25 (37\%) пацієнтів, серед яких 20 (51\%) жінок та 5 (17\%) чоловіків, а в 43 (63\%) пацієнтів - низький рівень, серед яких 24 (83 \%) - чоловіків, а 19 (49\%) - жінок.

По-різному реагували пацієнти залежно від профілю відділення. У 14 (74 \%) пацієнтів гінекологічного профілю, 9 (24 \%) - хірургічного та 2 (17\%) - травматологічного виявлено середній рівень напруження, в той час, коли низький рівень був наявний у 10 (83\%) пацієнтів з травматологічними патологіями, в 28 (76 \%) - з хірургічними захворюваннями та у 5 (26\%) - $з$ гінекологічними.

Також $є$ різниця серед реакцій у пацієнтів різних вікових категорій. Проведене дослідження показало, що у віковій групі 21-35 років усі 14 (100\%) пацієнтів мали лише низький рівень напруження. Серед обстежених вікової групи 35-55 років 16 (38 \%) пацієнтів перебували у стані середнього напруження, а 26 (62 \%) низького, а серед пацієнтів старшої вікової групи 55-76 років 9 (75 \%) - у стані середнього напруження, а 3 (25\%) - низького.

Після обробки результатів за шкалою «Втечауникнення» високий рівень напруження виявлено у 48 (71 \%) пацієнтів, середній рівень - в 19 (28 \%) осіб, а низький - у 1 (1\%).

Серед обстежених пацієнтів 27 (93\%) осіб чоловічої статі мали високий рівень напруження, 2 (7 \%) - середній. А серед жінок високий рівень мали 21 (59\%) пацієнтка, середній - 17 (44\%), низький - 1 (3\%).

Різнилась реакція і серед пацієнтів залежно від профілю операційного втручання. Так у пацієнтів травматологічного профілю високий рівень напруження виявлено в 10 (83 \%) осіб і лише у 2 (17\%) - середній. Серед пацієнтів хірургічного профілю високий рівень напруження мали 28 (77 \%) пацієнтів, а середній 9 (24\%). Серед пацієнтів гінекологічного профілю високий рівень напруження виявляли у 10 (53\%) пацієнтів, середній - у 8 (42\%), а низький - в 1 (5\%).

Під час підготовки до операційного втручання всі 14 (100\%) пацієнтів вікової групи 21-35 років мали високий рівень напруження, у віковій групі 35-55 років у 29 (69 \%) пацієнтів був високий рівень, а в 13 (31\%) середній. У віковій групі 55-76 років у 5 (42 \%) пацієнтів виявлено високий рівень напруження, у 6 (50 \%) - середній рівень, а в 1 (8\%) - низький рівень.

Оцінка стану напруження за шкалою «Планування рішення проблеми» у 23 (34 \%) пацієнтів виявила високий рівень, серед яких було 18 (46 \%) жінок та 5 (17\%) чоловіків, у 44 (65\%) пацієнтів - середній рівень, з яких 24 (83 \%) чоловічої статі та 20 (51\%) жіночої; а в 1 (1\%) особи жіночої статі виявлено низький рівень.

Проведене нами дослідження показало, що серед пацієнтів гінекологічного профілю виявлено 10 (53 \%) пацієнтів із високим рівнем напруження, 8 (42 \%) - з середнім і 1 (5\%) - 3 низьким. Серед пацієнтів хірургічного профілю 11 (30 \%) осіб мали високий рівень напруження, а 26 (70 \%) - середній. Високий рівень напруження серед пацієнтів травматологічного профілю мав місце в 2 (17\%) пацієнтів, а середній - у 10 (83\%).

Неоднозначні показники виявлено залежно від віку обстежених пацієнтів. У 5 (36 \%) осіб, які належали до вікової групи 21-35 років, виявлено високий рівень напруження, а в 9 (64 \%) - середній. Серед пацієнтів вікової групи 35-55 років високий рівень виявлено у 9 (21\%) пацієнтів, а в 33 (79\%) - середній. У віковій групі 55-76 років високий рівень напруження мав місце у 9 (75\%) пацієнтів, середній - в 2 (17\%) пацієнтів і низький - у 1 (8 \%) пацієнта.

У передопераційний період за шкалою «Позитивна переоцінка» мав місце високий рівень напруження у 31 (45,6 \%) пацієнта, середній рівень - в 36 (53\%), а низький - у 1 (1,4\%).

Серед обстеженої групи пацієнтів високий рівень напруження виявлено у 19 (66 \%) чоловіків та 12 (31 \%) жінок; середній рівень - у 26 (66,5 \%) жінок та 10 (34\%) пацієнтів чоловічої статі; в той час, коли низький рівень наявний у 1 (2,5 \%) жінки.

Була наявна різниця у показниках залежно від профілю захворювання, з приводу якого пацієнта готували до операційного втручання. Так у 10 (83 \%) пацієнтів травматологічного профілю виявлено високий рівень напруження, а в 2 (17\%) - середній. Серед пацієнтів із гінекологічними захворюваннями високий рівень мав місце у 8 (42 \%) осіб, в 10 (53\%) - середній та у 1 (5\%) - низький. В той час 13 (35\%) пацієнтів хірургічного профілю мали високий рівень напруження, а 24 (65 \%) - середній.

Як виявилось, має значення і вікова група, оскільки показники відрізняються залежно від вікової категорії. Серед групи 21-35 років у 10 (71 \%) пацієнтів спостерігають високий рівень напруження, у 4 (29\%) - середній. У віковій групі 35-55 років високий рівень наявний у 21 (50\%) пацієнта, а в 21 (50 \%) - середній. Серед вікової групи 55-76 років середній рівень напруження був 11 (92 \%) пацієнтів, а в 1 (8 \%) - низький.

74 ISSN 2411-1597. МЕДСЕСТРИНСТВО. 2020. № 2 
Проведене нами дослідження показало, що всі пацієнти, яких готують до операційного втручання, перебувають в стані підвищеного напруження, проте ступінь його прояву значною мірою залежав від статі, віку та профілю втручання, до якого готують пацієнта. Нами встановлено, що жінки мали вищий ступінь напруження порівняно з чоловіками за шкалою «Конфронтаційний копінг», «Дистанціювання», «Пошук соціальної підтримки», «Прийняття відповідальності», «Планування рішення проблеми», тоді як у чоловіків за шкалою «Самоконтроль», «Втечауникнення». Такі результати свідчать про те, що жінки здатні давати опір труднощам, вміють відстоювати власні інтереси, використовують інтелектуальні прийоми раціоналізації, вміють сконцентровувати увагу на інші речі, взаємодіють з людьми, очікують на підтримку зі сторони, пораду та співчуття, вони визнають свою роль у виникненні проблем та відповідальні за їх вирішення; вміють аналізувати ситуації за рахунок чого вирішують проблеми, в той час як чоловіки справляються з негативними переживаннями за рахунок цілеспрямованого придушення та стримування емоцій, мінімізації їх впливу на сприйняття ситуації і вибір стратегії поведінки, вони прагнуть до самоволодіння, також вони здатні реагувати на труднощі за типом відхилення, тобто заперечують проблему, фантазують та мають неоправдані очікування.

У результаті проведеного дослідження встановлено, що пацієнти наймолодшої вікової групи (21-35 років) мають високий рівень напруження за шкалами «Конфронтаційний копінг», «Пошук соціальної підтримки», «Втеча-уникнення», «Позитивна переоцінка», а найстаршої вікової категорії (55-76 років) - за шкалами «Дистанціювання», «Прийняття відповідальності» та «Планування рішення проблеми», пацієнти середньої вікової групи (35-55 років) мають середній рівень напруження. Отримані результати свідчать про те, що пацієнти молодшої вікової групи вирішують проблеми за рахунок не завжди цілеспрямованої поведінкової активності, залучаючи зовнішні ресурси, шукаючи інформаційну та емоційну підтримку, але в той же час вони здатні заперечувати проблему, тоді як люди старшої вікової категорії суб'єктивно знижують значення проблеми за рахунок гумору, переключення уваги на інші речі, але вони розуміють свою роль у виникненні проблеми і несуть відповідальність та планують стратегію щодо їх вирішення. Пацієнти середньої вікової групи в силу свого адаптаційного потенціалу особистості мають середній рівень напруження.
Підсумовуючи, варто зазначити, що пацієнти, яких готували до операційного лікування з приводу травматологічної патології, мали високий рівень напруження за шкалами «Конфронтаційний копінг», «Пошук соціальної підтримки», «Втеча-уникнення», «Позитивна переоцінка», що свідчить про властивість особистостей до опору труднощам, але із залученням соціальних ресурсів, інформаційної та емоційної підтримки, вони здатні заперечувати наявні проблеми та схильні до фантазування, однак можуть розглядати проблему як стимул для особистісного зростання. Серед пацієнтів хірургічного профілю високий рівень напруження виявлено за шкалою «Дистанціювання», що свідчить про те, що дані пацієнти справляються з негативними переживаннями за рахунок суб'єктивного зниження їх значення, користуються прийомами раціоналізації та заперечення, а гінекологічного профілю - за шкалами «Прийняття відповідальності», «Планування рішення проблеми», що свідчить про те, що дані пацієнти здатні на самокритику та самозвинувачення, вони переборюють проблеми за рахунок аналізу ситуації і можливих варіантів поведінки.

Висновки. 1. Пацієнти, яких готують до операційного втручання, перебувають в стані напруження, ступінь якого залежить від статі, віку та характеру операційного втручання.

2. Особи жіночої статі мають вищий ступінь напруження порівняно з чоловіками за шкалою «Конфронтаційний копінг», «Дистанціювання», «Пошук соціальної підтримки», «Прийняття відповідальності», «Планування рішення проблеми», тоді як у чоловіків за шкалою «Самоконтроль», «Втеча-уникнення».

3. Молоді пацієнти віком 21-35 років мають високий рівень напруження за шкалами «Конфронтаційний копінг», «Пошук соціальної підтримки», «Втеча-уникнення», «Позитивна переоцінка», а вікової категорії 55-76 років - за шкалами «Дистанціювання», «Прийняття відповідальності» та «Планування рішення проблеми». Пацієнти вікової групи 35-55 років мають середній рівень напруження за всіма шкалами даної методики.

4. Пацієнти, яких готували до операційного лікування з приводу травматологічної патології, мали високий рівень напруження за шкалами «Конфронтаційний копінг», «Пошук соціальної підтримки», «Втеча-уникнення», «Позитивна переоцінка», хірургічного - за шкалою «Дистанціювання», а гінекологічного профілю - за шкалами «Прийняття відповідальності», «Планування рішення проблеми». 


\section{СПИСОК ЛІТЕРАТУРИ}

1. Гостищев В. К. Общая хирургия : учебник / В. К. Гостищев. - М. : ГЭОТАР-Медиа, 2016. - 752 с.

2. Шапошников В. И. Научные проблемы в здравоохранении (поиск путей их решения) : монография / В. И. Шапошников. - М. : Издательский дом Академии Естествознания, 2019. - 100 с.

3. Гоженко А. И. Основы построения теории болезни : монография / А. И. Гоженко. - Одесса : Фенікс, 2015. - 84 с.
4. Барабанов Р. Е. Основы медико-психологических знаний с клиникой патологий : учебное пособие для высших учебных заведений / Р. Е. Барабанов. - М. : Московский финансово-юридический университет МФЮА, 2016. - 232 с.

Отримано 09.04.20 